\title{
Project Quality Management Lifecycle: A CaSe Study of the Commencement of Insulin Pen Mass Production
}

\author{
Martin Januska, Adam Faifr \\ ${ }^{a}$ University of West Bohemia, Univerzitni 8, Pilsen 30614, Czech Republic
}

\begin{abstract}
Goal of the paper is to demonstrate practical application of project quality management during whole lifecycle of Project of introduction and manufacture of insulin pen. Project quality is divided to quality of project management process and quality of the project product. Both of these aspects are described on a practical example by using Quality Management Tools in paper. First part deals with project management process and the concept of quality management is described. This part outlines procedure of quality planning and system of quality assurance. Costs to assure quality are also mentioned. The second part describes the system of product checking and also deals with quality of testing and cleanliness of production environment. Used methods and tools are evaluated from practical point of view after application in case study.
\end{abstract}

Keyword: project quality management; quality management tools; quality plannig; system of quality assurance; product quality
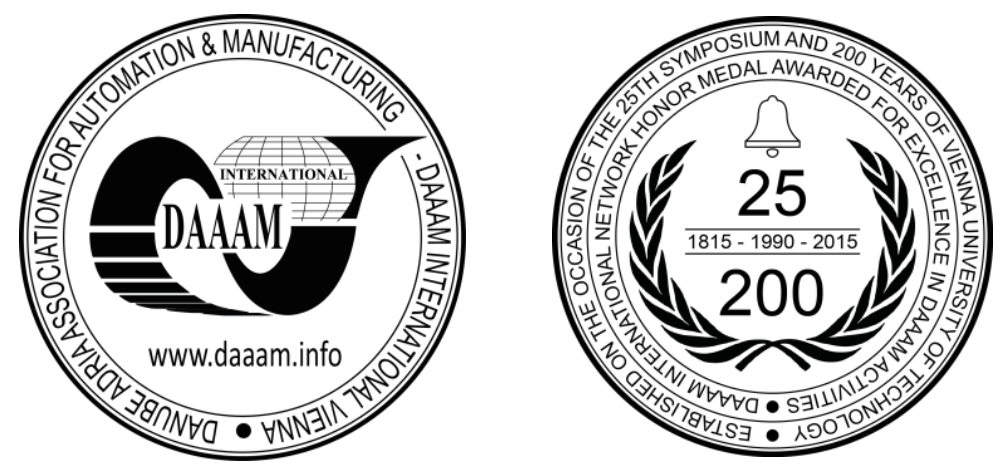

This Publication has to be referred as: Januska, M[artin] \& Faifr, A[dam] (2016). Project Quality Management Lifecycle: A Case Study of the Commencement of Insulin Pen Mass Production, Proceedings of the 26th DAAAM International Symposium, pp.0343-0349, B. Katalinic (Ed.), Published by DAAAM International, ISBN 978-3-90273407-5, ISSN 1726-9679, Vienna, Austria

DOI:10.2507/26th.daaam.proceedings.046 


\section{Introduction to contemporary project quality management}

Goal of the paper is to demonstrate practical application of project quality management during whole lifecycle of Project of introduction and manufacture of insulin pen from two points of view. First point of view deals with project management process and the concept of quality management. Procedure of quality planning and system of quality assurance and tools are practically described here demonstrating that no new or innovative tools are used and quality can be maintained just through combination of common tools. Costs to assure quality are also mentioned. The second view describes the system of product checking and also deals with quality of testing and cleanliness of production environment.

In general project can be described as unique set of processes carried out within an exact time period and utilizing of certain inputs $[13,11]$. Uniqueness is the main difference between project and process, therefore poor quality of any step in whole project can cause poor quality or failure of whole project.

Management system based on processes and the related control functions which are consolidated and combined into a functioning unified system with goal to reach the certain limits is called project management.

Mentioned goal to execute any project is to meet certain needs which will in the future bring the desired benefits. Such goal is referred to as the product of the project. However, same goal can be achieved under different circumstances and therefore is important to combine various processes in a fashion to reach best possible outcomes respectively project quality. Quality of project product is essential but quality of project processes must be taken in to the account because is directly linked with quality of product. Project management therefore deals with both of these aspects of quality $[14,9]$.

\subsection{Contemporary quality management}

Rather than a matter of improving the output control or the introduction of new administrative measures, quality management is nowadays primarily a matter of human resources and their abilities [20]. Instead of looking at quality as a technical issue today the quality is nowadays understand in the terms of customer satisfaction, not primarily by increasing production and profits [9].

Together with change of perception of the quality the orientation at the product is also changing to orientation at process and system based on continual improvement and precise analysis of errors, their anticipating and introduction of corrective measures. High quality product is still important but to follow high quality process is important as well. By following the right process we should reach the right product. All errors needs to be detected, analyzes and corrective actions taken to prevent the errors to appear again. Tools analyzing possible errors are utilized to estimate possible risks. Gradually we are shifting from quality control point of view to quality management set in a fashion that error did not even occur. This leads to the significant decrease in cost related with quality control and low quality products [3, 22].

\subsection{Quality management in environment of pharmaceutical industry}

For the needs of specific sectors (such as pharmaceuticals), which differ in their demands on management form of quality control based on industry standards was developed. It fully respects the structure of the requirements of ISO 9001, however it adds many other requirements and defines specific requirements that are typical for the industry. It finds its application just as in the pharmaceutical industry. Here we are working with the concept of so-called Good Manufacturing Practice a guidance system in compliance with the directives and regulations of the institutions that, for example, issuing permits and licenses for the production and distribution of food, pharmaceuticals and active pharmaceutical products. One reason for the emergence of this concept is the fact that due to its versatility a mere application of ISO 9000 is for some sectors inadequate [7].

or the production of goods in the healthcare industry environment is unconditional fulfillment of all the regulations and rules based both on ISO 9000 and ISO 13485 standards [1] specifying the requirements for a quality management system specifically for the development and manufacture of medical devices and ISO 14001 [4] dealing with environmental management. Other requirements are then determined by medical products laws or EU directives.

Of all these standards is noticeable emphasis on the health and safety of consumers. Any defect or deficiency can in fact in this case lead to serious consequences.

\section{Case study - project solostar}

Project of introduction of the insulin pen SoloStar in to production was selected for case study. Project take place in company Gerresheimer Horsovsky Tyn Ltd. in Czech Republic an is a part of Gerresheimer MDS group which is a major producer of a wide range of medical equipment and medical products. Customer of the project in this case is other international pharmaceutical company Sanofi SA.

At the moment, the insulin pen SoloStar in the Czech Republic is produced and supplied to the customer as two components, Mechanism Subassembly and Cap/Cartridge Holder. They consist of a total of 12 plastic parts created by injecting molten plastic in injection molding and externally supplied metal spring. Sanofi SA than completes pen 
with vial of insulin and sells complete device to final customer. At the moment production of 100 million pieces each year is estimated (approximately 275 thousand units per day) [5].

\subsection{Concept of quality management}

Quality is in terms of Gerresheimer group managed by universal system. Project management system is therefore similar for each project and is governed by the following hierarchy:

1. Quality Management Handbook (QMH)

2. Descriptions of processes and procedures (SOPs)

3. Work Instructions

4. Forms

5. The completed documents (records).

From the project management point of view the quality can be divided in to the three basic parts: quality planning, quality assurance and operational quality management. [12, 15, 17, 18]

\subsection{Quality planning}

To ensure the project overall quality it must be well planned. Planning of any project in the company Gerresheimer is based on the five-stage model. This ensures that any activity that might later compromise product quality is not missed. A key output of quality planning is a plan for ensuring the quality of the project. It serves as a basis for further quality assurance throughout the project.

Quality assurance plan at the following picture is processed in the form of a matrix which defines the various activities at the various stages of the project, which would lead to required quality. At the same time it is necessary to meet all these activities in order to enable the project to move into its next phase. In the event that some activities taking place over several phases (eg, project risk management the interim performance report on activities is formed at the end of the stage).

There is also a sort of manual for compliance, defining individual activities, the inputs and outputs, persons who are responsible for the operations, authorizing officer and the person who is to be inform about the activities is defined based on the method RACI [16]. All these activities have also determined time frame so that the project is carried out according to the schedule.

\subsection{Quality assurance}

Corresponding Gate Reviews are performed upon reaching each milestone and risks are evaluated and recorded in product and process FMEA. While in DFMEA logs all risks affecting the quality of the product and preventive actions PFMEA logs risks that could negatively affect individual processes and the quality of the entire project [16].

At the end of the fourth phase (Figure 1 Module 6 pre-production), validation of production on the basis of Good Manufacturing Practice is performed. Procedure for the validation is shown in the flowchart of Figure 2.

Validation starts by Design Qualification (DQ), showing that production facilities are able to produce the specified product. Installation Qualification demonstrates that all the devices are installed and adjusted according to the production concept. Operational Qualification (OQ) tests whether the machine actually manufactures products according to the given specifications. The company Gerresheimer adds Performance Qualification (PQ) which verifies that the device is able to produce prescription products in the required volume. After all these tests successfully completed regular production can start $[6,8,10,18,21]$.

To ensure efficiency Gerresheimer process management system has established procedures for registration, measurement, analysis and improvement. For these measurements, it uses statistical methods in which these measures key performance indicators of quality (KPI). These indicators allow to measure the quality of the project and maps the weaknesses in the system that could be improved and indicates the potential deterioration of the running of the process. For the project SoloStar were defined KPI indicating both the process of manufacture and assembly, but also the quality of the management of complaints, expedition and based on measuring the cost of non-conforming product even process quality control.

In 2014 the share of project turnover in the total turnover of company was $23.38 \%$. Costs for quality assurance of the project at the time of realization of project (for 2015) are estimated at $16.4 \%$ of the project budget. In terms of the cost of quality assurance project envisages a budget with spending on inspections, product testing, monitoring their processes and acquisitions and maintain its own control devices. Additional costs for quality assurance are expenses associated with complaints (testing of defective products, complaints procedure). 


\begin{tabular}{|c|c|c|c|c|c|}
\hline $\begin{array}{c}\mathrm{Q} \\
\text { module } \\
\mathrm{S}\end{array}$ & Phase I & Phase II & Phase III & Phase IV & Phase V \\
\hline 1 & $\begin{array}{c}\text { M1: } \\
\text { Q phase review: } \\
\text { Input variables from } \\
\text { the previous Gate } \\
\text { present }\end{array}$ & $\begin{array}{c}\text { M1: } \\
\text { Q phase review: } \\
\text { Input variables from } \\
\text { the previous Gate } \\
\text { present } \\
\end{array}$ & $\begin{array}{c}\text { M1: } \\
\text { Q phase review: } \\
\text { Input variables from } \\
\text { the previous Gate } \\
\text { present } \\
\end{array}$ & $\begin{array}{c}\text { M1: } \\
\text { Q phase review: } \\
\text { Input variables from } \\
\text { the previous Gate } \\
\text { present }\end{array}$ & $\begin{array}{c}\text { M1: } \\
\text { Q phase review: } \\
\text { Input variables from } \\
\text { the previous Gate } \\
\text { present }\end{array}$ \\
\hline n.a. & Product concept & & & & \\
\hline n.a. & $\begin{array}{l}\text { Check of the } \\
\text { requlatory } \\
\text { requirements }\end{array}$ & & & & \\
\hline 2 & $\begin{array}{l}\text { Purpose of medical } \\
\text { device class }\end{array}$ & & & & \\
\hline 2 & $\begin{array}{l}\text { M2: Risk } \\
\text { Management Plan } \\
\text { corresponding to } \\
\text { ISO14971 }\end{array}$ & $\begin{array}{l}\text { M2: Risk } \\
\text { Management Plan } \\
\text { corresponding to } \\
\text { ISO14971 }\end{array}$ & & & \multirow{7}{*}{$\begin{array}{l}\text { M9: Support for } \\
\text { production location }\end{array}$} \\
\hline 3 & & $\begin{array}{c}\text { M3: Risk } \\
\text { management }\end{array}$ & $\begin{array}{c}\text { M3: Risk } \\
\text { management }\end{array}$ & $\begin{array}{c}\text { M3: Risk } \\
\text { management }\end{array}$ & \\
\hline $4 / 5$ & Specifications & $\begin{array}{c}\text { M4: Design } \\
\text { verification planning }\end{array}$ & $\begin{array}{c}\text { M5: Design } \\
\text { verification } \\
\text { implementation } \\
\text { Supplement PMF }\end{array}$ & & \\
\hline $4 / 5$ & & $\begin{array}{l}\text { M4: Design validation } \\
\text { planning }\end{array}$ & $\begin{array}{l}\text { M5: Design validation } \\
\text { implementation } \\
\text { Supplement PMF }\end{array}$ & & \\
\hline $6 / 8$ & \multirow{2}{*}{ Production concept } & $\begin{array}{l}\text { Detailing of the } \\
\text { manufacturing } \\
\text { processes }\end{array}$ & \multirow{2}{*}{$\begin{array}{c}\text { M6: Process } \\
\text { Validation Preparation } \\
\text { Validation Master Plan } \\
\text { Create PMF DQ, IQ, } \\
\text { OQ }\end{array}$} & \multirow{2}{*}{$\begin{array}{l}\text { M6+M8: Process } \\
\text { Validation } \\
\text { Preparation } \\
\text { VMP-DQ / /Q / OQ } \\
\text { Create/hand over } \\
\text { PMF } \\
\text { PQ } \\
\text { Process Validation } \\
\text { Summary Report }\end{array}$} & \\
\hline $6 / 8$ & & $\begin{array}{l}\text { Finalization of } \\
\text { packaging }\end{array}$ & & & \\
\hline 7 & $\begin{array}{c}\text { Supplier } \\
\text { search/selection }\end{array}$ & $\begin{array}{l}\text { Conclude supplier } \\
\text { selection }\end{array}$ & $\begin{array}{l}\text { M7: Quality of the } \\
\text { outsourced processes } \\
\text { and purchased parts }\end{array}$ & & \\
\hline 1 & $\begin{array}{c}\text { M1: } \\
\text { Q phase review: } \\
\text { Input and output } \\
\text { variables from the } \\
\text { Gate present }\end{array}$ & $\begin{array}{c}\text { M1: } \\
\text { Q phase review: } \\
\text { Input and output } \\
\text { variables from the } \\
\text { Gate present }\end{array}$ & $\begin{array}{c}\text { M1: } \\
\text { Q phase review: } \\
\text { Input and output } \\
\text { variables from the } \\
\text { Gate present }\end{array}$ & $\begin{array}{c}\text { M1: } \\
\text { Q phase review: } \\
\text { Input and output } \\
\text { variables from the } \\
\text { Gate present }\end{array}$ & $\begin{array}{c}\text { Conclusion of } \\
\text { project }\end{array}$ \\
\hline
\end{tabular}

Fig. 1. Quality assurance plan

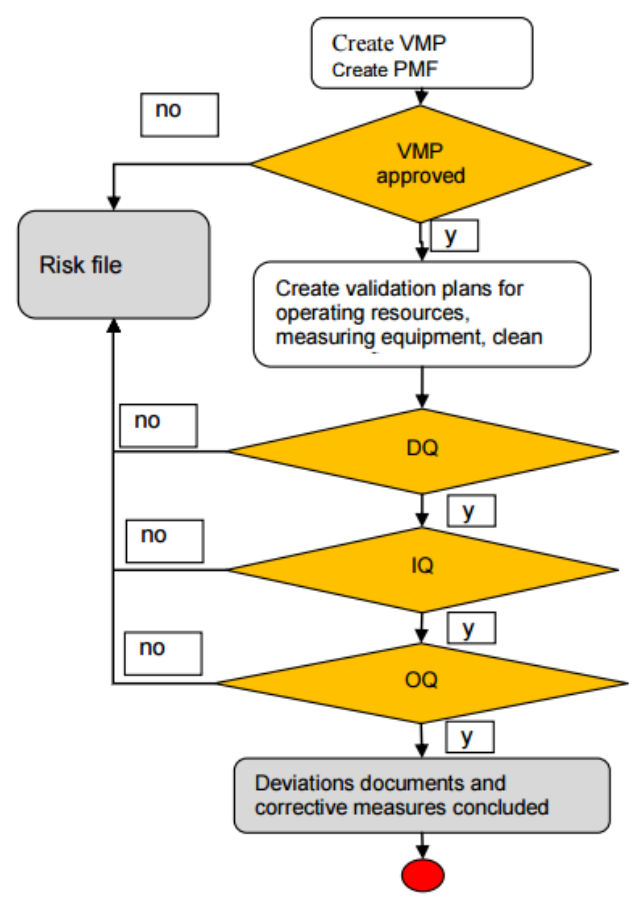

Fig. 2. Process validation preparation (Module 6) 


\subsection{Operational quality management}

The aim of operating quality control of the project is to monitor all activities of the project, which could end up by internal or external complaints. Both types of complaints from a procedural point of view it looks identical. Complaints are usually caused by either a non-conforming products or non-conforming processes. In the case of nonconforming process is also envisaged that all product that has been developed within it is also not consistent. In the event that a system of quality control found any process or product for non-conforming, or if the customer claims it, the complaint procedure is immediately initiated. $8 \mathrm{D}$ report is created in each complaint procedure.

\subsection{Product Control}

Project product is mass production of insulin pen components. A prerequisite for a quality product, which will ensure that for a given volume is not too expensive, is to ensure maximum sterile environment (ie. Free of dust and other mechanical limit pollution) and adequate calibration and professional work.

The system of controls has been defined during pre-production phase of the project. Part of the controls carried out was introduced based on customer requirements (Sanofi), who also determine how and at what intervals controls will be conducted. Only samples of batches depending on the long-term quality are tested. It would be almost impossible to test every single part and some of the tests are destructive. Further tests and inspections are defined by the company itself, to be able to identify potential problems and especially its cause.

The control system begins with input control of all raw materials delivered, (the plastic granulate and metal spring). Process controls can be divided into control of parts, ie. The individual parts produced on injection molding machines and control of finished pen components.

Semi finished product control consist of visual testing of samples for visible defects, such as burrs or tan on the edges of plastics and dimensional test on automatic equipment. In case of finding defects another part of the batch is controlled. Each control is logged and statistically processed. At following picture it is possible to see the results of the tests of Outer Body part using a control chart and histogram. The results show that the dimensions of products moving in close proximity to the optimum value (i.e. in thousandths of a millimeter). From the histogram it is again evident that the measured values are about the desired ideal value or slightly less.

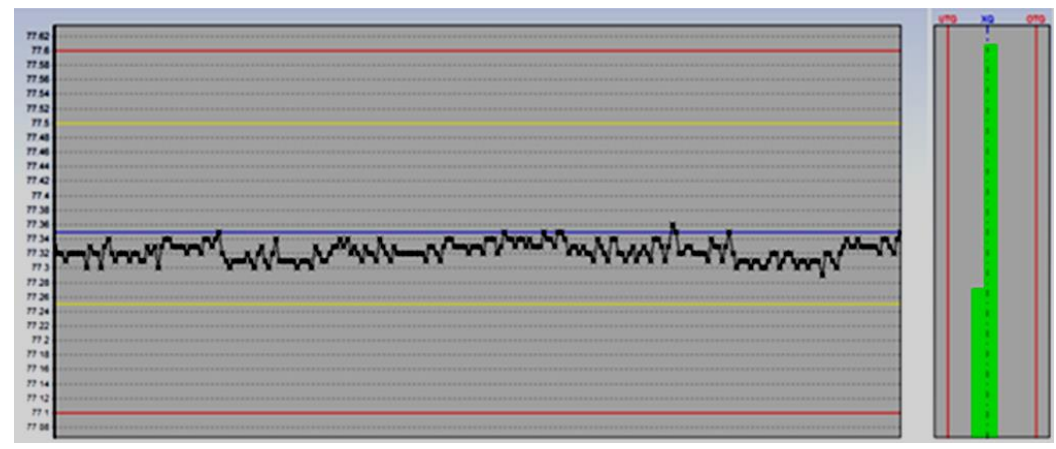

Fig. 3. Control chart and Histogram of Outer Body

In case of crossing the regulation limit the production on machine will stop and whole batch will be scraped. Installation components control consist again of a visual examination and adds a function test - absolutely crucial for the production. The test is carried out on the device ATE (Automatic Testing Equipment). Torque and power of injection is measured. For torque tolerance ranges in hundredths of nanometers from the optimum value, for the injection force the tolerance is set to 0.5 Newton. If the device is not available, this test may be performed after prior approval manually. ATE test results are documented and subsequently at weekly intervals provided to the customer. One defect in thousand opportunities is allowed by customer.

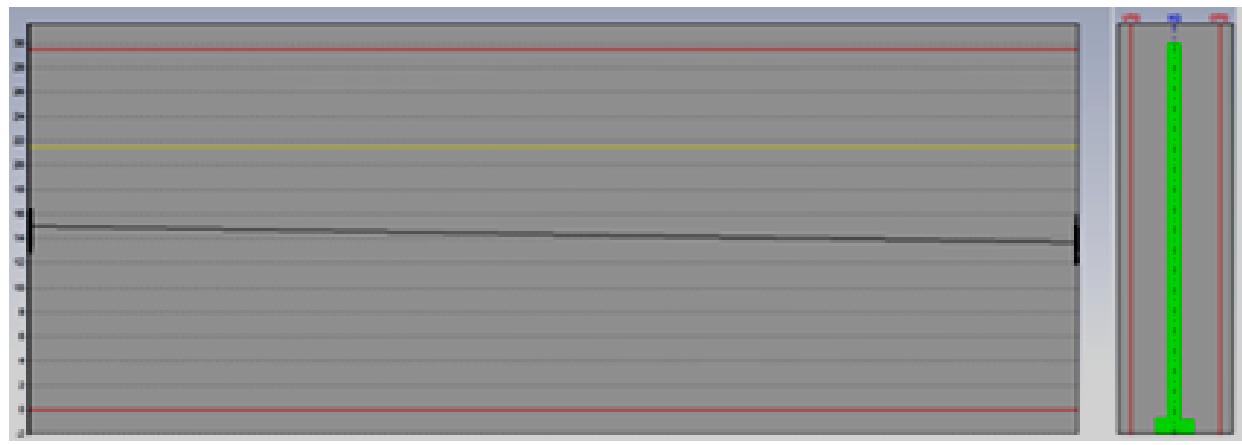

Fig. 4. Injection force of Mechanism Subassembly 


\subsection{Quality of controls}

All parts are measured several times during the manufacturing process. To ensure that the measurement is relevant it is essential to secure flawless function of all measurement devices and expert use of all devices.

All injection molding machines and other manufacturing equipment must be validated (or calibrated) before production and must be ensured that this state was maintained throughout whole production. Production devices are also able to identify the problem during production, and its activity is automatically interrupted (JIDOKA). The same rules apply to all Werth control measuring equipment, optical measuring instruments and ATE devices. Calibration mark is assigned after successfully checking to all of these devices. It is placed at the device and contains the date of the next calibration.

Employee expertise to operate the device play significant role in the quality control as well. Trainings are organized based on need or customer demand as part of the planed budget for department or the customer cover the cost.

\subsection{Cleanliness of production environment}

Besides meeting the requirements resulting from sectoral standards and requirements for cleanliness, company manages and controls the quality of the environment also due to the direct influence at product quality.

To ensure the quality of products is necessary to maintain the entire production environment disinfected, so as to avoid the slightest contamination. Production area is strictly separated from other areas of the company and the special regulation applies here. Every worker must before entering into the production and control areas undergo disinfection. This is to ensure that the hairs, hair or other particles such as clothing or shoe soles do not get into contact with the produced parts and production facilities and thus adversely affect their quality.

\section{Conclusion}

As can be seen at the example project SoloStar, concept of quality management based solely on controlling finished products is now almost unusable. Quality of SoloStar project has been managed since its inception, where all the activities have been carefully planned. Quality management through whole project lifetime minimizes the risk that future production will suffer with quality problems. On the other hand, quality control in the early phase of the project means greater need for funds before the start of the production itself. However, this "investment" will bring in the future if the right measures will be applied not only savings, but also significant decrease in the potential and recurring problems. In a production environment annually producing 100 million units, with each product consists of 13 parts, it is virtually impossible to check each component or it is possible but cost will be too high. Good planning of future production, without forgetting the core important activities leads to the minimizing of the risks.

Unlike systems based solely on control of manufactured product in this case there is a risk for the final consumer to use potentially dangerous product endangering his health. Companies in the pharmaceutical industry must have implemented a quality management system and must comply with the regulation beyond ordinary business, but this itself does not guarantee that production will be without errors, only decreases the risk. Manufacturing quality must be maintained at high level and must consider all the aspects that may affect it. Properly set up of quality management system will allow in case of defects much efficiently find root cause of a problem in time. This system must be based on a careful record of all data. In the event that certain data are not sufficiently recorded, or not recorded at all, root cause can not be detected because the investigation is based on misleading information that will lead to a different result. In this regard, the concept of production quality management (Quality by Design) must be more accurate than a system based on the checking of each single product (the Quality Control). Disorder in any process may have had serious consequences.

As described in whole case study the quality system of the project consist of combination of commonly used tools for statistical control and project management. Tools are implemented through whole lifetime of project which in the result leads to the savings in cost related to quality. The cost for quality management itself is higher but the total cost linked to poor quality significantly decreases. All the tools described are commonly known by the regular managers of lead employees. They must just be appropriately combined and effectively used.

Our further research is targeted at the root causes during whole production lifetime registered in complaint process, whatever the problems are caused by manufacturing or non-manufacturing process.

\section{References}

[1] Abuhav, Itay. ISO 13485: a complete guide to quality management in the medical device industry. Boca Raton: CRC Press, c2012, xi, 361 p. ISBN 14-398-6611-2.

[2] Brue, Greg. Six sigma for small business. Irvine, Calif.: Entrepreneur Press, c2006, xvi, 208 p. ISBN 19-3253155-6. 
[3] Chaudary, Samra, Sohail Zafar a Mehrukh Salman. Does total quality management still shine? Re-examining the total quality management effect on financial performance. Total Quality Management. 2014, 26(7-8): 811-824. DOI: $\quad 10.1080 / 14783363.2014 .895521$. ISSN $1478-3363$. http://www.tandfonline.com/doi/full/10.1080/14783363.2014.895521

[4] Edwards, A. ISO 14001 environmental certification step by step. Rev. 1st ed. Burlington, MA: Elsevier Butterworth-Heinemann, 2004, xiii, 246 p. ISBN 0750661003.

[5] Faifr, A. Project Quality Management. Bachelor thesis. Pilsen: 2015

[6] Halevi, Gideon. Handbook of production management methods. [Online-Ausg.]. Oxford: Butterworth-Heinemann, 2001. ISBN 07-506-5088-5.

[7] Isnyrlis, Vasileios a Odysseas Moschidis. The use of quality management systems, tools, and techniques in ISO 9001: 2008 certified companies with multidimensional statistics. Total Quality Management. 2014, 26(5-6): 497-

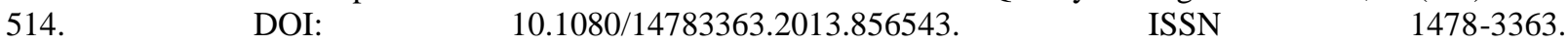
http://www.tandfonline.com/doi/abs/10.1080/14783363.2013.856543

[8] Januska, M., Stastna, L. Industrial Engineering in the Non-Manufacturing Processes. In Proceedings of The 22nd International Business Information Management Association Conference.: International Business Information Management Association (IBIMA), 2013. s. 747-766. ISBN: 978-0-9860419-1-4

[9] Kloppenborg, Timothy J a Joseph A Petrick. Managing project quality. Vienna, Va.: ManagementConcepts, c2002, xv, 120 p. ISBN 15-672-6141-8.

[10] Kudrna, J., Miller, A., Edl, M. Methods of industrial engineering in network organizations. In Creating Global Competitive economies - A 360-degree Approach. Milan: International Business Information Management Association (IBIMA), 2011. s. 2037-2042. ISBN: 978-0-9821489-6-9

[11] Nagarajan, K. Project management. 2nd ed. New Delhi: New Age International, 2005. ISBN 81-224-1557-1.

[12] Nenadal, Jaroslav. Moderní management jakosti: principy, postupy, metody. Vyd. 1. Praha: Management Press, 2008, 377 s. ISBN 978-80-7261-186-7.

[13] Robersts, Paul. Effective project management. Philadelphia, PA: Kogan Page, 2011, x, 291 p. ISBN 07-494-61586.

[14] Rose, Kenneth. Project quality management: why, what and how. Boca Raton, Fla.: J. Ross Pub., c2005, xiii, 173 p. ISBN 1932159487.

[15] Skalický, Jiří, Milan Jermář a Jaroslav Svoboda. Projektový management a potřebné kompetence. 1. vyd. Plzeň: Západočeská univerzita v Plzni, 2010, xiii, 389 s. ISBN 9788070439753.

[16] Stamatis, D. Failure mode and effect analysis: FMEA from theory to execution. 2nd ed., rev. and expanded. Milwaukee, Wisc.: ASQ Quality Press, 2003, xxxi, 455 p. ISBN 08-738-9598-3.

[17] Zeng, Jing, Chi Anh Phan a Yoshiki Matsui. The impact of hard and soft quality management on quality and innovation performance: An empirical study. International Journal of Production Economics. 2015, 162: $216-226$. DOI: $\quad$ 10.1016/j.ijpe.2014.07.006.

ISSN

09255273. http://linkinghub.elsevier.com/retrieve/pii/S0925527314002230

[18] Achim, M.I., Dragolea, L.-L. The importance of quality control in firms' activity, (2012) 23rd DAAAM International Symposium on Intelligent Manufacturing and Automation 2012, 2, pp. 1099-1102.

[19] Kristjuhan, K., Metsla, E., Ling, H. Quality of management practices and application of complex automated systems (2012) Proceedings of the International Conference of DAAAM Baltic "Industrial Engineering", pp. 163168. ISBN: 978-994923265-9

[20] Prochazkova, Petra Tausl; Jelinkova, Eva. The Importance of Intellectual Capital in Entrepreneurial Companies. Proceedings of the 6th European Conference on Intellectual Capital. Academic Conferences and Publishing International Limited Reading, 2014, pp.249-254. ISBN 2049-0941978-1-909507-24-1.

[21] KUNG, Kao-Hui, Chin-Fu HO, Wei-Hsi HUNG a Chuan-Chun WU. Organizational adaptation for using PLM systems: Group dynamism and management involvement. Industrial Marketing Management [online]. 2015,2015 11-23, 44: 83-97 DOI: 10.1016/j.indmarman.2014.04.018. ISSN 00198501.

[22] KITAJIMA, Teiji, Yukiyasu SHIMADA, Tetsuo FUCHINO a Kiyotaka BITO. Production Management Integrating Safety, Quality and Productivity. KAGAKU KOGAKU RONBUNSHU [online]. 2014, 2015-11-23, 40(3): 187-193 DOI: 10.1252/kakoronbunshu.40.187. ISSN 0386-216x 